\title{
The design and construction of Gallions surface water pumping station
}

\section{G. H. TOWNSEND \& I. S. S. GREEVES}

\section{Mr A. W. Shilston, Consulting Engineer}

This is a scheme which provides an admirable subject for case history study. 104. It is conventional in an industrial type project that the desired process plant layout arrangements largely determine the building structure form. The impression created by this Paper is that substructure design/construction considerations dictated the layout of this substantial sewage-handling installation. Such approach would not appear to have produced any problems in building superstructure design. All that has to be asked then, on the broad conceptual aspect, is whether it can be assumed that the resulting (unusual) plant layout imposed by overall capital cost considerations has caused no disquiet to those responsible for operation and maintenance.

105. Overall design, construction, plant installation and commissioning being so interlocked, have the Authors any views on how a repeat scheme might be orchestrated with increased facility through changed contractual arrangement $\xi^{\prime}$, assuming that the listed subcontractors were nominated by the Employer to the main civil engineering contractor and conventional standard form contract conditions prevailed, generally. Behind that question perhaps could be kept in mind that the Paper is silent on how the activities, on site, of the principal mechanical and electrical contractors were co-ordinated.

106. On more detailed points, mindful that the pumps were selected to be capable of passing a $100 \mathrm{~mm}$ sphere $(\S 18)$, what was the bar spacing of the mechanically swept protecting screens?

107. Regarding the ground conditions ( $\$ 32-35$ ), were the results of the ten-day pumping tests conveyed to tendering contractors and was the revealed subsoil water pattern susceptible to seasonal influences?

108. On substructure design, in evaluating steel-sheet-piled circular cofferdam construction versus diaphragm wall construction, it no doubt was intended that the permanent construction would be built independently of the steel sheet piling, but was it contemplated in the appraisal that the entirety of the piling would be extracted successfully with a saleable value on disposal as second-hand piling?

109. $\S 58$ indicates that it was intended that the finish of the outer (diaphragm) wall of the wet well would be that left by the trench excavation cutting tool.

Paper published: Proc. Instn Civ. Engrs, Part 1, 1979, 66, Nov., 605 624. 
In the event, was the resulting unprepared finish deemed acceptable for a sewage sump? What was the indicative spacing of the nodal joints on the diaphragm walls, and on resumption of normal rest conditions in the subsoil water, before plant commissioning, were any unacceptable leakages observed at those points, calling for treatment? If so, how was that achieved?

\section{Mr Townsend and Mr Greeves}

With the experience of just over 18 months of operation and maintenance which has, in fact, included some extensive work to rectify problems on both the mechanical and electrical installations, it would be quite true to say that no major disadvantage has been highlighted by the layout of the station. On the contrary in certain cases access has been available where denied normally, thus enabling inspection without the need to dismantle. The biggest disadvantage seems to be the reverberating echo which makes shouted communication between levels very difficult.

111. Contractual arrangements were not as Mr Shilston assumes, as civil mechanical and electrical contractors had separate contracts with the Employer. The reason for this was that the mechanical and electrical contractors were unwilling to enter into an ICE form of subcontract. The arrangement is not fully successful in respect of construction co-ordination, although it definitely has merit in the commissioning and maintenance period context in eliminating a third party who knows nothing about the plant and at that stage becomes a reluctant participant involved only contractually.

112. At Beckton the activities of the three contractors were co-ordinated by the consulting engineer. The disputes and difficulties dealt with were in many cases undoubtedly those that would have normally arisen and been dealt with just as effectively by the main contractor in the conventional relationship.

113. With reference to $\S 106$, there was a clear distance of $75 \mathrm{~mm}$ between the bars of the mechanically raked screens.

114. The results of the pre-contract pumping tests were made available to tenderers. Due to the nature of the dewatering system of pumping from deep wells it would be difficult to be conclusive about seasonal fluctuations in groundwater flow from that evidence, but it is doubtful from general experience in the area whether this is significant.

115. The matter is further complicated by the sympathetic variation of level of $+1.0 \mathrm{~m}$ to $-1.0 \mathrm{~m}$ from Ordnance Datum with the tidal waters of the nearby Thames which has been observed when pumping from trench excavations and from boreholes.

116. The use of sheet piles was not pursued by the contractor for the outer wall because.

(a) heavy circular steel framing would be costly to supply and remove during the construction of the permanent works inside such a cofferdam;

(b) it was known that piles would be driven to refusal in the dense Thanet Sand;

(c) the cost of removal, if possible, would quite likely have been as much as the second-hand value of the piles themselves.

117. As referred to in $\S 28$, the natural finish of the diaphragm wall was considered acceptable at design stage, bearing in mind that the sewage is rainwater 
from a separate system of sewers. Joints in the diaphragm walls were $3.2 \mathrm{~m}$ spacing and required no treatment for leakages. Since the pumping system only lowered the water inside the chamber the pressure on the outside remained constant and kept the wall in sufficient pressure at all times to prevent any leaks between individual joints. 